\title{
The Political Economy of Unsustainable Fiscal Deficits*
}

\author{
Roberto PASTEN \\ Universidad de Talca \\ JAMES P. COVER \\ The University of Alabama
}

This paper uses an intertemporal model of public finances to show that political instability can cause taxes to be tilted to the future, resulting in a fiscal deficit that is suboptimal and only weakly sustainable (in the sense of Quintos). This occurs because political instability gives the government an incentive to implement a myopic fiscal policy in order to increase its chances of remaining in office. The government achieves this by delaying taxes (or advancing spending) in order to buy political support, which in turn causes an upward trend in the deficit process and a financial crisis. Using annual data for Chile for the 1833-1999 period, we present statistical test results that support the model.

JEL: E62, H21, H62

Keywords: Fiscal Policy, Political Instability, Weak and Strong Sustainability, Cointegration with Change in Regime

\section{INTRODUCTION}

The history of many developing countries shows that political crises and budgetary fiscal crises often occur together. Some notable examples are Indonesia 1998, Argentina 2002, Ecuador 1999, Russia 1998, Venezuela 1902, Bolivia 1985, and Chile in both 1891 and 1973. For example, the three largest government deficits in Chilean history occurred during the 1971-1973 period. This period of financial instability ended after a military junta took power during the winter of 1973, also ending several decades of political instability. Similarly, the fourth largest deficit in Chilean history (and the largest of the $19^{\text {th }}$ century) occurred in 1891, the same year President José Manuel Balmaceda was deposed in a bloody civil war, bringing closure to a three-decade-long power struggle between the Chilean Congress and the Presidency.

\footnotetext{
* Raimundo Soto and two anonymous referees provided useful insights. Any other errors are ours. E-mail: rpasten@utalca.cl
} 
Another legislative-presidential dispute reached a crisis point in Russia during 1993. Although President Boris Yeltsin of Russia won the initial battle and succeeded in pushing through a constitution establishing a strong presidency, the new government's ability to make debt payments was almost constantly in doubt. Finally, in August 1998 Russia defaulted on both its domestic and foreign debt. At the end of the following year President Yeltsin resigned and Vladimir Putin became president. This ended, at least temporarily, both the political and the fiscal crisis.

To illustrate this phenomenon, Figure 1A shows central government revenue and spending (as a share of GDP) and Figure 1B shows central government fiscal deficit (as a share of GDP) in Bolivia for the period from 1970 to 2003. According to the data, between 1970 and 1985 the deficit increased dramatically from $2 \%$ to more than $40 \%$ of GDP, a period during which Bolivia had 14 different presidents (an average of one president per year).

Solimano (2003) shows that ten of these presidents did not complete their term in office because of a coup, resignation or some other form of extraconstitutional, forced removal (see Table 1). This period of political instability finally ended when Victor Paz Estenssoro became president in 1985. Notably, the government's fiscal crisis ended as well, with the budget being practically balanced from 1986 to 1991.

TABLE 1

BOLIVIA: PRESIDENTIAL CRISES, 1970-1997

\begin{tabular}{|c|c|c|c|}
\hline (Crisis year) & President & Pres. period ${ }^{\mathrm{a}}$ & Deficit \\
\hline$(1970)$ & A. Ovando & 1969-1970 & 1.93 \\
\hline \multirow[t]{2}{*}{$(1971)$} & J.J. Tores & 1970-1971 & 3.86 \\
\hline & H. Banzer & 1971-1978 & 2.98 \\
\hline (1978) & J. Pereda & 1978-1979 & 3.99 \\
\hline (1979) & D. Padilla, W. Guevara, A. Natush & 1979-1979 & 7.37 \\
\hline (1980) & L. Gueiler & $1979-1980$ & 7.92 \\
\hline$(1981)$ & L. Garcia & 1980-1981 & 6.81 \\
\hline$(1982)$ & C. Torrelio, A. Mariscal, G. Vildoso & 1981-1982 & 27.74 \\
\hline \multirow[t]{4}{*}{$(1985)$} & H. Siles & $1982-1985$ & 33.38 \\
\hline & V. Paz & 1985-1989 & 0.97 \\
\hline & J. Paz & 1989-1993 & 2.53 \\
\hline & G. Sanchez & $1993-1997$ & 3.21 \\
\hline
\end{tabular}

Source: Solimano (2003). The names of presidents who did not complete their period because of a coup, resignation or non-voluntary removals are highlighted. The crisis year is shown in brackets. a. Presidential period until the crisis. 
FIGURE 1 (A)

BOLIVIA: TOTAL REVENUE AND TOTAL SPENDING

1960-2000

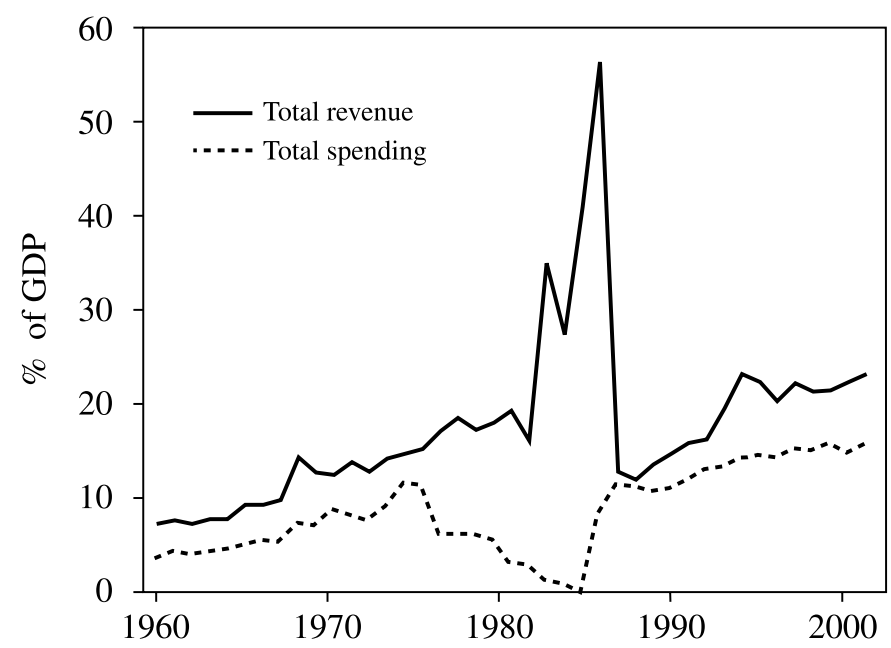

Source: Oxford Latin America Economic History Database.

FIGURE 1B

BOLIVIA: FISCAL DEFICIT

1960-2000

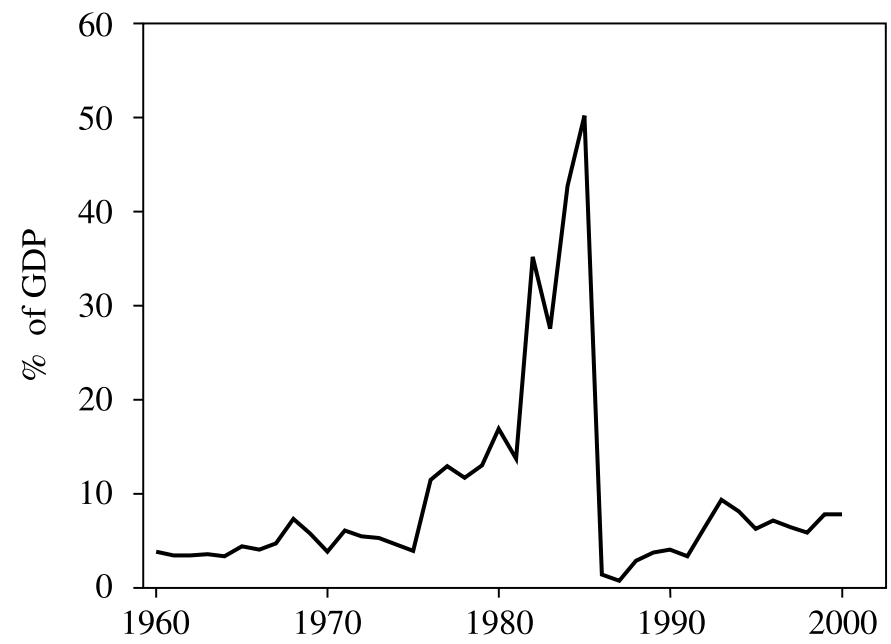

Source: Oxford Latin America Economic History Database. 
These are just a few examples of many which indicate that there is an association between political instability and fiscal crisis in developing countries. Scholars who address this association tend to focus their attention on the political consequences of economic policies, as do Chang (2007), Haggard (2000) and Frankel (2005). Similarly, Panzer and Paredes (1991) and Cerda and Vergara (2007, 2008) examine the political consequences of economic policies in Chile.

This paper, however, shows that there is something to be learned by turning this relationship around and examine the consequences of politics in developing countries on economic policy. The pioneering work in this regard is Nordhaus's paper (1975) on political business cycles. Nordhaus develops a model of opportunistic politicians manipulating pre-electoral economic variables (such as unemployment and inflation) in order to increase the likelihood of reelection. With backwardlooking agents, the incumbent has an incentive to induce a boom during the period immediately previous to an election without any worry that voters will take into account the possibility of a recession occurring afterwards.

One of the main criticisms of Nordhaus's model is the key role assigned to the Phillips curve. In his model, the incumbent government promotes inflation-inducing policies to reduce unemployment while fiscal policies play no role. This is at odds with the empirical evidence presented by a number of authors including Rogoff (1990), Drazen (2000), Gonzalez (2002), and Cerda and Vergara (2008) that implies that fiscal policy is an important tool of preelectoral manipulation. The paper by Cerda and Vergara (2008) analyzes the effect of government subsidies on presidential elections in Chile and finds that the greater the coverage of subsidies, the greater the number of votes received by the incumbent.

One model that considers fiscal policies as a tool for pre-electoral manipulation is Rogoff's (1990) model of political budget cycles (PBC). In this model, a politically motivated policy maker induces a tax cut (or an increase in spending) prior to election day with a consequent increase in taxes (or decrease in spending) afterwards, creating a cycle in the government's budget deficit.

The model employed in our study differs from PBC models in one very important aspect. In PBC models, it is assumed that changes in power occur only on an election day so that the probability that an officeholder will remain in power during any given electoral period is always equal to one. Hence, there is no uncertainty about the length of tenure in office other than uncertainty about the outcome of the next election. In an unstable democracy, however, as suggested by the discussion in the first three paragraphs of this paper, the probability of remaining in office between electoral periods may be less than one, rendering the tenure period uncertain. Therefore, in the model developed below, as long as there is uncertainty about the length of tenure in office, the sure-thing post-electoral period as assumed by PBC models is never reached and therefore the decline phase of the budget cycle is never realized. As long as the probability of remaining in office between elections is less than one, the deficit will be trend-driven rather than cyclical, thereby increasing the probability of a sovereign debt crisis. 
In this paper political instability exists if the incumbent officeholder believes that the probability of remaining in office one more period is less than one. It is assumed that the officeholder is a ruling party with uncertain length of tenure because of political uncertainty. Based on these assumptions, a benevolent but politically unstable government places less weight on future welfare than it would under political stability. This causes the fiscal deficit to follow a time series process with at least one unit root and therefore, government debt is accumulating at a relatively fast rate. As a result, any shock to government revenues (or an adverse shock to a government's ability to borrow) is more likely to cause a sovereign debt crisis under political instability than under political stability (Quintos, 1995). Hence, our model implies that political instability increases the probability of a government financial crisis.

The potential for financial crises to be caused by political instability has not received much attention in the literature. Frankel (2005) indirectly addresses the issue when he wonders why the worst speculative attacks associated with several foreign exchange crises during the 1990s occurred after an election rather than before it. The explanation Frankel offers is similar to the hypothesis proposed in this paper. A "devaluation is politically costly to leaders, and so in an election year they try to postpone it, whether to get reelected, or so that the crash comes on their successors' watch rather than their own, or out of the hope that something will turn up to improve the balance of payments" (Frankel, 2005 , p. 7). This paper argues that a similar explanation is valid for fiscal crises. Taxes are politically costly to government both directly and indirectly through their distortionary cost. If the officeholder faces a positive probability of losing power, he or she would prefer to defer taxes to the future while, in the meantime buying political support through increased expenditures that cause a positive trend in the fiscal deficit.

Consider the following scenario. Suppose a government finds that it is losing popular support. It does not matter whether the government was popularly elected; it may need to increase its popular support to avoid losing power. This decline in popular support gives it an incentive to "purchase" support either by reducing taxes or increasing spending in ways that it believes will increase its political support. It can only do this through increased borrowing. As a result, the budget deficit will begin to trend upward as the government's political position weakens. (A rising deficit can occur for other reasons as well.) But whether or not the increased spending (or decreased taxes) increases the government's support, the rising debt will eventually increase the government's default risk. If the potential for default means the government will have to cut back on expenditures that were buying political support, then the increased probability that this spending will eventually come to an end causes the government to lose support and eventually lose power.

This paper explores this idea for a particular developing country, Chile, between 1833 and 1999. If the premise of this paper is correct, then points in time when structural fiscal reforms occur (structural breaks in the fiscal deficit series) will also be points in time at which there is an important political change. 
The debt will drop after the regime which attempts to buy political support loses power. The debt will grow once again when a regime sees the political need to begin buying political support through expansion of government programs.

The policy implications of this paper are strong: Financial resources such as those provided by the International Monetary Fund and other multilateral funding organisms may not be as useful as has been believed unless a profound reform in political institutions is first accomplished. Moreover, financial support may even be damaging under these circumstances (Caballero and Dornbush 2002).

This paper is organized as follows: The next section presents the model which adds the political instability variable to the models of (Barro, 1979) and Ghosh (1995) and shows that if political instability exists, then the cointegrating vector between taxes and government spending can be written as $[1 \gamma]$ with $0<\gamma<1$. Section 3 studies the order of integration of fiscal series for Chile between 1833 and 1999. Section 4 examines the stability of the cointegration vector $[1-\gamma]$ between total revenue and total spending. If $\gamma<1$, the level of political instability is high and, therefore, points in time with the highest likelihood of $\gamma$ being less than one are expected to correspond to periods of political unrest. Section 5 analyzes endogenous break-points in the cointegration rank between taxes and spending. It provides evidence of two regimes in the time series process followed by budget deficits in Chile: a first regime with $\gamma<1$ and a second regime with $\gamma=1$ and with taxes and government spending cointegrated. Finally, we look to history to tell us if the breakpoint found corresponds to a time of political and fiscal reform. Final remarks are presented in Section 6 and our conclusions are in Section 7.

\section{Intertemporal Model of Fiscal Deficit}

Gosh (1995) uses Barro's (1979) tax-smoothing model to derive the optimal path of taxes and therefore of the fiscal deficit given the path of government spending by a benevolent government. During any period $t$, the government chooses a tax path that minimizes the present value of the distortionary cost of taxes:

$$
C_{t}=\frac{1}{2} \sum_{s=t}^{\infty} \beta^{s-t} E\left[\tau_{s}^{2} \mid I_{t}\right], \quad 0<\beta<1 .
$$

According to (1) the distortionary cost of non-lump sum taxes during any period $s$ is proportional to the square of the average tax rate during the period, $\tau_{s}$ defined to be total collection of taxes divided by GDP (See also Bohn (2005) and Pasten and Cover (2010a)) In equation (1) $E$ is the expectation operator, $I_{t}$ is the information set available to the government during period $t$, and $\beta$ is the government's subjective discount factor. It is assumed that the government minimizes (1) subject to its dynamic budget constraint:

$$
D_{t+1}-D_{t}=r \cdot D_{t}+\left(G_{t}-\tau_{t} \cdot Y_{t}\right)
$$


where $D_{t}$ is the stock of government debt at the beginning of period $t, G_{t}$ is the exogenous level of government expenditures (net of interest) in period $t, Y_{t}$ is output during period $t$, and $r$ is the constant real interest rate. The left hand side of (2) defines the fiscal deficit, $D E F_{t}$, and can be iterated forward to yield:

$$
\sum_{s=t}^{\infty} \frac{1}{(1+r)^{s-t}} \tau_{s} Y_{s}=(1+r) D_{t}+\sum_{s=t}^{\infty} \frac{1}{(1+r)^{s-t}} G_{s}+\lim _{s \rightarrow \infty} \frac{1}{(1+r)^{s-t}} D_{s+1}
$$

Dividing each variable in (3) by $Y_{t}$ and assuming output grows at the constant rate $n$ allows the intertemporal budget constraint (IBC) to be written as:

$$
\sum_{s=t}^{\infty} R^{s-t} \tau_{s}=(1+r) d_{t}+\sum_{s=t}^{\infty} R^{s-t} g_{s}+\lim _{s \rightarrow \infty} R^{s-t} d_{s}
$$

where lower-case letters represent the corresponding variables now expressed as a share of output, and $R=(1+n) /(1+r)<1$ is the effective discount factor. Applying a similar normalization to the one period budget constraint (2) yields:

$$
(1+n) d_{t+1}=(1+r) d_{t}+g_{t}-\tau_{t}
$$

In finance literature it is common to interpret a non-zero value for the limit term in (4) as a bubble. Hence, for many authors (e.g., Trehan and Walsh, 1988, 1991; Cashin et al., 1998; Hakkio and Rush, 1991; Hamilton and Flavin, 1986; Quintos, 1995) a non-zero value for $\lim R^{s-t} d$ indicates that the process generating $d_{t}$ is non-sustainable. Otherwise, ${ }^{s \rightarrow \infty}$

$$
\lim _{s \rightarrow \infty} R^{s-t} d_{s}=0
$$

Minimizing (1) subject to (5) and (6) yields the optimal tax rate for each period:

$$
\left.\tau_{t}=\gamma\left[(r-n) d_{t}+\bar{g}_{t}\right)\right]
$$

where $\bar{g}_{t}=(1-R) \sum_{s=t}^{\infty} R^{s-t} E_{t}\left(g_{s}\right)$ is the permanent value of government spending, while

$$
n \gamma=\left[\frac{1-\left(R^{2} / \beta\right)}{1-R}\right]
$$

is the tax-the tilting parameter. The value of $\gamma$ depends upon whether the government places a relatively low weight on the future $(\beta<R$ which implies $\gamma<1)$, the same weight as the market $(\beta=R$ which implies $\gamma=1)$, or a relatively high weight $(\beta>R$ which implies $\gamma>1)$. 
If the government discounts the future at a relatively high rate (and thus $\beta$ is relatively low), then it is said that taxes are tilted toward the future because the government must increase taxes over time in order to service its accumulating debt. (This follows because $d_{t+1}>d_{t}$ for any $t$ during which $\gamma<1$.) As a result there is an upward trend or drift in the government's debt. On the other hand, if the government discounts the future at the same rate as the market, then $\beta=R$ and $\gamma=1$ and it is said that there is no tax tilting. In this case expected tax revenue (as a share of output) does not change over time unless there is a change in permanent government spending. When $\gamma=1$ the government is following the tax-smoothing model and (to use the terminology of Ghosh (1995) and Cashin et al. (1999)) the resulting fiscal deficit is called the tax-smoothing component of the fiscal deficit. Equation (7) implies that the tax-smoothing component of the deficit can be defined as:

$$
d e f_{t}^{*}=g_{t}^{r}-\gamma^{-1} \tau_{t}
$$

Where $d e f_{t}^{*}$ is the tax-smoothing component of the deficit and $g_{t}^{r}=(r-n) d_{t}+g_{t}$ represents public spending inclusive of interest. Since the model implies that $d e f_{t}^{*}$ is stationary, if both $\tau_{t}$ and $g_{t}{ }^{r}$ are integrated variables then (9) defines a cointegrating relationship and $\gamma^{-1}$ can be estimated by regressing $g_{t}^{r}$ on $\tau_{t}$, or alternatively, $\gamma$ can be estimated by a reverse regression of $\tau_{t}$ on $g_{t}^{r}$.

The main empirical interest of this paper is whether the parameter $\gamma$, the tax-tilting parameter, behaves in a manner consistent with the idea that political instability causes financial instability. Since the fiscal deficit grows more rapidly if there is tax tilting $(\gamma<1)$, then we would expect to find a value of $\gamma$ less than one only during periods of relatively high political instability.

Pasten and Cover (2010b) present one way in which the value of $\gamma$ can depend on political stability. They assume that the government discount factor equals the probability that the government will stay in power $(p \leq 1)$ times the market discount factor, or $\beta=p R .^{1}$ This changes the expression for the tilting parameter in $(8)$ to

$$
\gamma=\left[\frac{1-(R / p)}{1-R}\right],
$$

A reduction in $p$, the probability of survival, indicates a higher degree of political instability.

A few other authors have suggested that the degree of tax-tilting is dependent on the degree of political instability. For example, Cashin et al. (1999,

\footnotetext{
1 The idea that the government discount factor equals the market rate times the probability of the government surviving one more period in Pasten and Cover (2010b) is derived from a model based on Blanchard's (1985) model of a consumer with an uncertain life expectancy, which in turn is based on the work of Yaari (1965). Huang and Lin (1993), Ghosh (1995) and Olekans (1996), who implicitly are assuming $p=1$, assume that the government discount factor equals that of the market.
} 
p.14) states that "Tax tilting could occur, for example, if the current government is unsure of its reelection prospects and therefore favors higher current debt levels than are implied by tax-smoothing, in order to exert an influence of the future spending activities of rival political parties who assume office ..." . Also, Cerda and Vergara (2008, p. 2479) write, "Hence, in an election in which the incumbent forecasts a difficult reelection, he/she might increase subsidies to increase his/her possibilities".

The greater the degree of political instability, the lower the probability that the government will remain in power, the lower the value of the tax-tilting parameter $\gamma$, the more rapidly government debt increases, and the greater the likelihood that a negative shock to government revenues will cause a fiscal crisis. In practice, the impending fiscal crisis either causes the government to fall, or the government falls and then a new government deals with the fiscal crisis. Hence, during a period leading up to a fiscal crisis we expect $\tau_{t}$ and $g_{t}{ }^{r}$ to grow (or drift upwards) and $\gamma<1$.

Econometrically, this implies that during periods of political stability in Chile, we expect to find that either (1) $\tau_{t}$ and $g_{t}{ }_{t}^{r}$ follow stationary stochastic processes, or (2) if they are nonstationary, they are cointegrated with a cointegrating vector of $[1 \gamma=1]$ in a regression of $\tau_{t}$ on $g_{t}{ }^{r}$. On the contrary, during a period of political instability, they must be integrated of at least order one, $I(1)$, and $\gamma<1$ in a regression of $\tau_{t}$ on $g_{t}{ }^{r}$. Although the transversality condition (6) continues to hold, causing the budget deficit to be sustainable in a mathematical sense, Quintos (1995, p. 410) calls this weak sustainability because if $\gamma<1$, "it is inconsistent with the government's ability to market its debt in the long run ... and has serious policy implications because a government that continues to spend more than it earns has a high risk of default and would have to offer higher interest rates to service its debt". A similar point is made by Bohn (2007).

The testing procedure then proceeds as follows. If $\tau_{t}$ and $g_{t}^{r}$ are each $I(1)$ for the whole period in Republican Chile (1833-1999), and $d e f_{t}$ (fiscal deficit as a share of GDP) is stationary, the conclusion is that the country's deficit has been strongly sustainable because it implies that $\tau_{t}$ and $g_{t}^{r}$ are cointegrated variables with $\gamma=1$. This is expected since in the long run countries do not go bankrupt ex post. Next, we search endogenously for structural breaks in the cointegration vector between taxes and spending in order to find periods with the highest probability of $\gamma<1$. As long as the order of integration of $\tau_{t}$ and $g_{t}^{r}$ is at least one, then, according to our model, such periods will be ones of relatively high political instability.

Finally, we test the null hypothesis $\gamma=1$ against the alternative $\gamma<1$. We expect this null to be rejected only if there is political instability. If the null is accepted it suggests that there is political stability (and $p=1$ in equation (10)). To implement it, we look for evidence of two regimes in the time series process followed by $\tau_{t}$ and $g_{t}{ }^{r}$ in Chile: a first regime with $\gamma<1$ and a second regime with $\gamma=1$ and with $\tau_{t}$ and $g_{t}{ }^{r}$ cointegrated. This allows us to define the latter as a period of strong sustainability in the fiscal deficit and therefore one of political stability. The analysis is applied to Chile during the 1833-1999 period. 


\section{Analyzing the Sustainability of the Fiscal Budget IN CHILE: 1833-1999}

This section analyzes the possible stationarity of the fiscal deficit in order to test the hypothesis that the deficit has been strongly sustainable over the long run between 1833 and 1999. The data for GDP, total expenditures, total revenue and the overall fiscal deficit for Chile's consolidated central government have been taken from a series rigorously constructed by Wagner et al. (2000) comprised of information for the Chilean fiscal sector from 1833 to 1999.

Figure 2 displays central government revenue and expenditures (as a share of GDP) for the period 1883-1999. As can be seen in the figure, both variables tend to meander around a trend. The apparent structural break that emerges around the middle of the 1970s is the result of structural reforms implemented by the military government of General Augusto Pinochet.

FIGURE 2

CHILE: TOTAL REVENUE AND TOTAL SPENDING 1833-1999

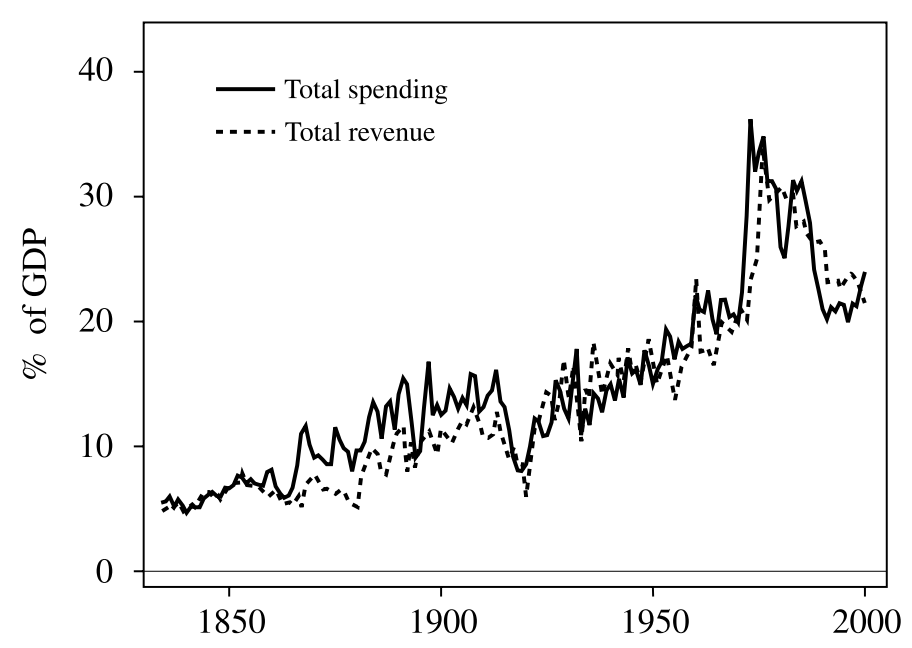

Source: Wagner et al. (2000).

According to the previous section, if the time-series process followed by the deficit is stationary, the null hypothesis that the fiscal deficit has been (strongly) sustainable cannot be rejected by the data. There can be no financial crisis if the deficit follows a stationary process. Column (2) of Table 2 presents a set of unit root tests for $d e f_{t}$ (fiscal deficit as a share of GDP). As can be seen from entries in the table, every statistic rejects the null hypothesis of a unit root in the fiscal deficit at conventional levels of confidence. Moreover, 
in every case the corresponding $z$-statistic fails to reject the absence of a trend in the series (not reported). The results presented in Table 2 therefore provide support for the proposition that over the long run, fiscal policy in Chile has been strongly sustainable.

TABLE 2

TESTS FOR UNIT ROOT IN DEFICIT: 1833-1999

$$
\Delta x_{t}=\alpha+\beta x_{t-1}+\pi_{t}+\sum_{j=1}^{p} \gamma_{j} \Delta x_{t-j}
$$

\begin{tabular}{lccc}
\hline & & \multicolumn{2}{c}{ Critical values } \\
\cline { 3 - 4 } & & $5 \%$ & $10 \%$ \\
\hline ADF & $-2,914(6)$ & $-2,886$ & $-2,576$ \\
GLS-DF & $-2,840(6)$ & $-2,021$ & $-1,712$ \\
$\operatorname{PP}(z(\rho))$ & $-41,972(6)$ & $-13,832$ & $-11,088$ \\
$\operatorname{PP}(z(t))$ & $-4,921(6)$ & $-2,886$ & $-2,576$ \\
\hline
\end{tabular}

Source: Authors' computations.

ADF: Augmented Dickey-Fuller Test; GLS-DF: GLS Dickey-Fuller Test; $\operatorname{PP}((z(\rho))$ : z $(\rho)$ PhillipsPerron Test; PP(z(t)): z(t) Phillips-Perron Test. In brackets the optimal number of lags (p) selected according to the Ng-Perron (1995) statistic.

\section{Stability of the Cointegration Vector: 1833-1999}

Figures 3 and 4 display estimates of the parameter $\gamma^{-1}$ obtained by applying the Johansen normalization method (Johansen, 1988) with robust standard errors to a rolling window of 51 observations. The first point in each figure is for the subsample 1833-1883, the second for the subsample 1834-1884, and so on. Since $\gamma<1$ implies political instability, we would expect that the samples with the highest marginal significance level in a one-tailed test of the null hypothesis $\gamma^{-1}=1$ against the alternative $\gamma^{-1}>1$ will end with those years in which there was a relatively high degree of political instability. (Adding a year of political instability increases the probability that the null is rejected.) These observations are identified by looking at the lower confidence interval in Figures 3 and 4 . According to Figure 3 which uses a 95\% confidence interval, the samples for which it is most likely that the null $\gamma^{-1}=1$ is rejected against the alternative $\gamma^{-1}>1$ end with the years 1885-1886, 1891-1892 and finally 1969-1976. Aside from the years 1885-1886 which are at the beginning of the sample, for the period 1891-1892 the highest point corresponds to the first of those years: 1891. For the period 1969-1976 the highest value corresponds to the year 1972 .

According to Figure 4 which uses a $99 \%$ confidence interval, there are only a few samples that reject the null hypothesis against the one-sided alternative. This reduces the number of samples with a possible structural break to those 
FIGURE 3

ROLLING WINDOWS 1833-1999

Conf. Interval 95\%

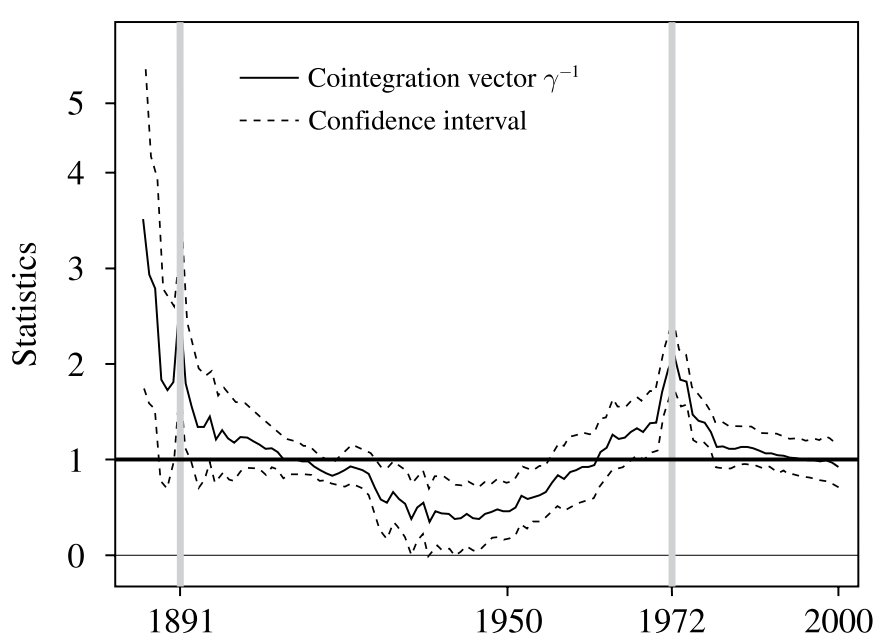

Source: Authors' computations.

Year corresponds to the last year of a sub-sample with 51 data points. Parameter estimated to be $\gamma^{-1}$ by a vector error correction (VEC) model with two lags in the short-run equation. Order of lags based in Ng-Perron (1995) sequential procedure.

that end in the year 1891 (when the country was experiencing a civil war) and each of the samples that end during the period 1969-1974. The sample with the highest marginal significance level ends with the year 1972 (one year before the coup d'etat that deposed President Allende).

In summary, statistically the highest probability for $\gamma^{-1}>1$ (or $\gamma<1$ ) and therefore the highest probability of deposition $(p<1)$ corresponds to years within the periods of time when in fact two presidents were overthrown. Furthermore, these events correspond to the most conflictive political periods in post-independence Chile.

\section{Stability of the Cointegration Rank: 1833-1999}

In this section the stability of the cointegration rank is studied rather than the cointegration vector between government spending and revenue because, as previously mentioned, some authors have argued that in order for the deficit to be sustainable, revenue and spending inclusive of interest payments (both as a share of GDP) must be cointegrated if both are I(1) processes.

One possible approach is to split the time series into two sub-samples, with 1973 as the cut-off point. However, this process could be biased, for several 
FIGURE 4

ROLLING WINDOWS 1833-1999

Conf. Interval 99\%

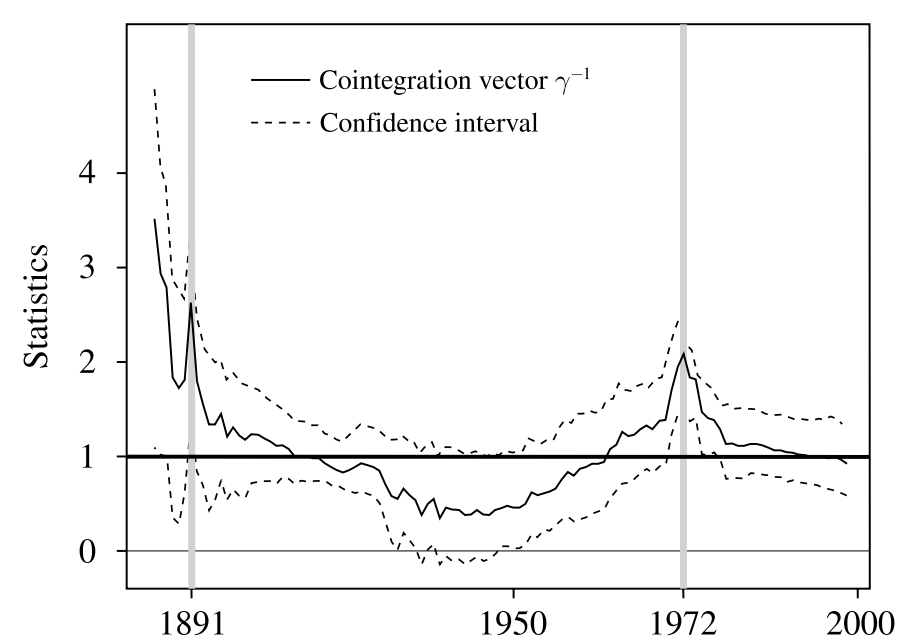

Source: Authors' computations.

Year corresponds to the last year of a sub-sample with 51 data points. Parameter estimated to be $\gamma^{-1}$ by a vector error correction (VEC) model with two lags in the short-run equation. Order of lags based in Ng-Perron (1995) sequential procedure.

reasons. First, the stabilization of fiscal policy after the military coup did not necessarily occur immediately; second, there are lags in the series that could generate some inertia; third, it is likely that the reforms applied at the beginning of the regime were modest; fourth, the military regime was not strongly settled immediately after taking power, and last (but not least given the context of this paper), assuming a specific cut-off point exposes the findings to the conventional criticisms in time series literature regarding the inclusion of exogenous breaks (Zivot and Andrews, 1992).

Therefore, in this paper we search for an endogenous structural break in the cointegration rank between total revenue and total spending. Figures 5 and 6 present results of a set of Johansen tests for the number of cointegration vectors sequentially estimated. In this procedure each window includes one more observation than the previous one, so that they grow in size from smallest (years 1833-1863, 31 data points) to largest which includes the entire sample (years 1833-1999, 167 data points).

Figure 5 presents the trace statistics (Johansen, 1988, 1991) for the null hypothesis of zero against the alternative of one cointegrating vector. Until the sample includes the year 1975 these trace statistics are below the critical value. Therefore, from 1833 to 1974 spending and taxes are, unambiguously, 
FIGURE 5:

SEQUENTIAL JOHANSEN TEST FOR ZERO COINTEGRATION VECTOR 1833-1999

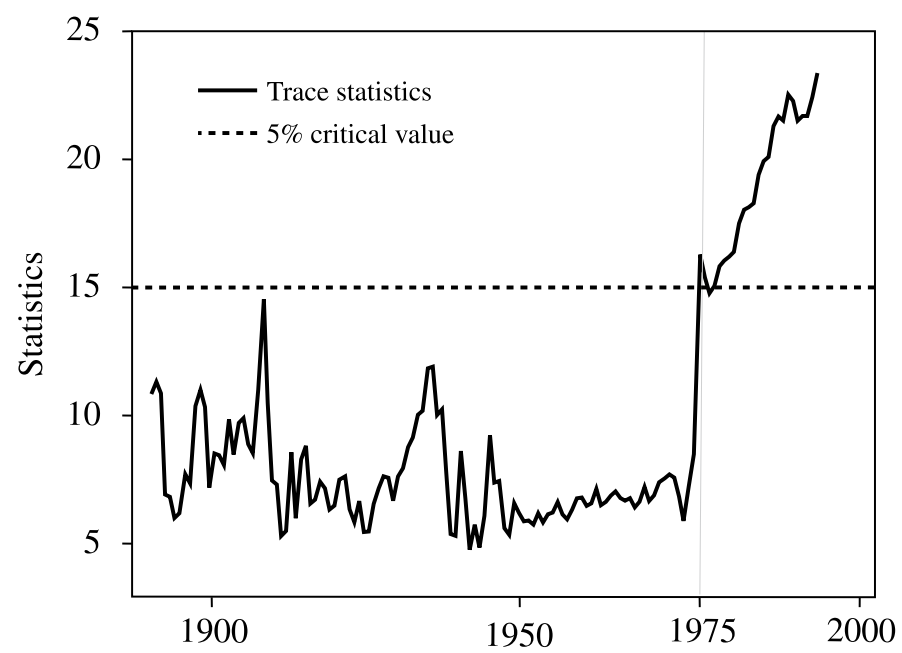

Source: Authors' computations.

Sequential trace statistics (Johansen 1988, 1991) for the null of zero cointegration vectors against the null of one cointegration vector. Year corresponds to the last year of a sub-sample with a fixed initial point in 1833. Parameter estimated by a VEC model with four lags in the short-run equation. Order of lags based on $\mathrm{Ng}$-Perron (1995) sequential procedure.

not cointegrated variables. Figure 5 also shows that from 1975 onward, the null hypothesis of zero co-integrating vectors "is rejected" against the alternative of one co-integrating vector.

In order to evaluate whether the variables are cointegrated starting in 1975 , it is necessary to test the null of one co-integrating vector against the alternative of more than one co-integrating vector. Figure 6 displays the trace statistic for this test and its corresponding critical value. Since the statistic is below its critical value the null of one co-integrating vector cannot be rejected against the alternative of more than one co-integrating vector and thus, starting in the year 1975, total revenue and total spending are cointegrated with one conintegrating vector.

However, as one referee has correctly pointed out, cointegration in the time series deficit process does not necessarily imply a probability of deposition equal to one. As mentioned above, not only must the two series be cointegrated, but it also must be the case that $\gamma=1$ in order for the deficit to be strongly sustainable. Therefore we use the residual-based tests for cointegration with regime change developed by Gregory and Hansen (1996) to analyze jointly the hypotheses of cointegration and $\gamma=1$. 
FIGURE 6

SEQUENTIAL JOHANSEN TEST FOR ONE COINTEGRATION VECTOR 1975-1999

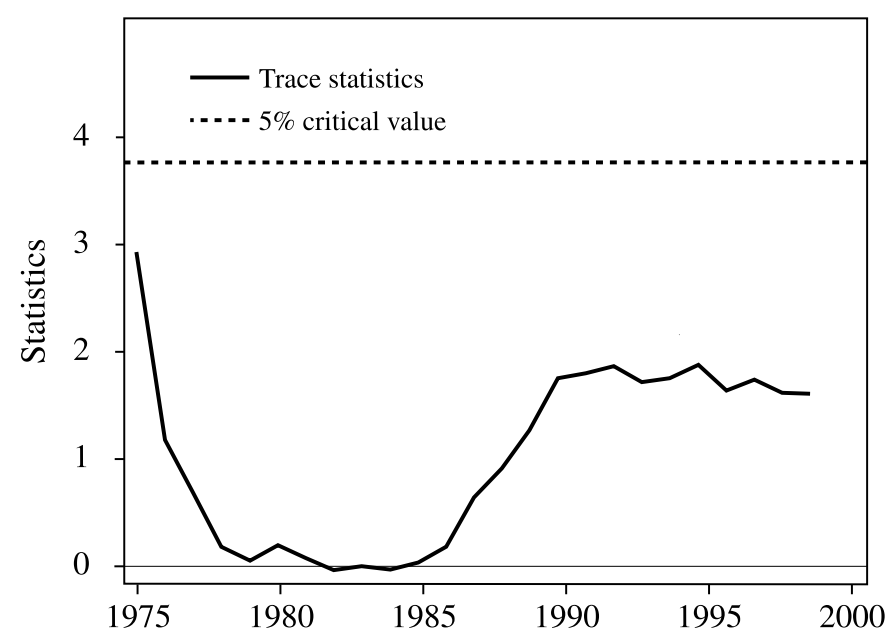

Source: Authors' computations.

Sequential trace statistics (Johansen 1988, 1991) for the null of one cointegration vectors against the null of more than one cointegration vector. Year corresponds to the last year of a sub-sample with a fixed initial original point in 1833 . Parameter estimated by a VEC model with four lags in the short-run equation. Order of lags based on Ng-Perron (1995) sequential procedure.

Gregory and Hansen (1996) modify the usual cointegration tests by allowing for the possibility of a change in the cointegration vector under the alternative hypothesis. Consider this equation for $\tau_{t}$ :

$$
\tau_{t}=\gamma_{1} g_{t}^{r}+\gamma_{2} g_{t}^{r} \varphi_{t-1}+e_{t}
$$

where $\gamma_{1}$ denotes the tax-tilting parameter before the regime shift and $\gamma_{2}$ denotes the change in the tilting parameter after the shift; $e_{t}$ is an $\mathrm{I}(0)$ stochastic error term and $\phi_{t-1}$ is the dummy variable defined as:

$$
\varphi_{t-1}=\left\{\begin{array}{ll}
0, & t \leq \Gamma \\
1, & t>\Gamma
\end{array}\right\}
$$

where the unknown parameter $\Gamma$ denotes the last observation before the regime change. The standard procedure proposed by Gregory and Hansen is a residual-based test of the null of no-cointegration against the alternative of cointegration with regime shift. The relationship given by (12) is estimated 
by ordinary least square (OLS) and Dickey-Fuller unit roots tests are applied to the regression residuals. Gregory and Hansen compute this test-statistic for each possible regime shift and choose as the breakpoint the one that yields the smallest value of the augmented Dickey-Fuller test statistic, $A D F^{*}{ }^{2}$ since the smallest value constitutes evidence against the null hypothesis. The break point with the smallest value is for $\Gamma=1975$ with $A D F^{*}=-5.59$. Since the critical value is -5.50 , the null hypothesis of no break is rejected and the alternative of a structural break in 1975 is accepted. ${ }^{3}$

Figure 7 plots the values of $\operatorname{ADF}(s)$ over the truncated sample. As mentioned, the smallest test-statistic occurred about 1975, while Table 3 presents the estimated coefficients for equation (12) estimated with a known breakpoint in 1975. The estimate of the tax-tilting parameter up to 1975 is 0.815 which statistically is significantly less than one, while the value after 1975 is 0.999 which does not differ statistically from one.

FIGURE 7

REGIME SHIFT WITH ADF

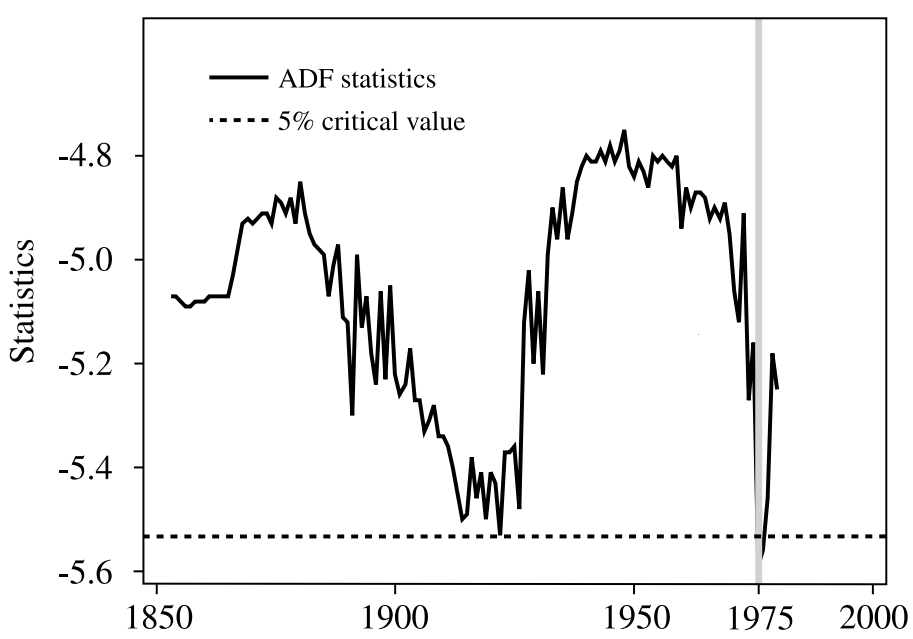

Source: Authors' computations.

2 Gregory and Hansen (1996) recommend that the sample of possible breakpoints exclude the first and last $15 \%$ of the overall sample. We reduced this to $10 \%$ to allow for breaks nearer the end of the sample. The lag truncation selected was $K=0$ for a similar reason.

${ }^{3}$ Critical value at the $5 \%$ level of significance is reported by Gregory and Hansen (1996) for the regime shift model with $m=2$ regressors (constant and slope). 
TABLE 3

ESTIMATION OF TAX/SPEND RELATIONSHIP WITH REGIME SHIFT: CHILE 1833-1999

\begin{tabular}{cc}
\hline Dependent variable $\tau_{t}$ & Coefficients \\
\hline$g_{t}^{r}$ & $0.8146^{* * *}$ \\
& $(0.032)$ \\
$g_{t}^{r} \varphi_{t-1}$ & $0.1845^{* * *}$ \\
& $(0.027)$ \\
$R^{2}$ & 1975 \\
Observations & 0.90 \\
\hline
\end{tabular}

Source: Authors' computations.

OLS regressions with structural shift. Dependent variable is total revenue, $\tau_{t}$. Standard errors in parentheses. $* * *$ denote significance at the 1 percent level.

\section{FinAL REMARKS}

Thus, we find that there is a structural break in the relationship between the time series processes followed by taxes and government spending in Chile. Does this conclusion make sense? The break occurs in 1975, less than two years after the violent coup that deposed President Salvador Allende. That year, President Pinochet consolidated his power over the country as well as his power over the junta, retaining sole chairmanship (this position was originally going to be rotated among the four branches of the armed forces) The measures implemented by members of Pinochet's economic team during those years were the most dramatic structural reforms ever in Chile's history. Furthermore, as summarized by Collier and Sater:

Yet the Chicago Boys by no means won an instant victory [at the beginning of the military regime]. At a moment of steeply rising prices and mounting unemployment, their austere vision of unrestrained capitalism seemed altogether too risky to many military men, not to mention business leaders. During 1974, however, Chile began to feel the effects of the devastating international recession caused by the "First Oil Shock"- the quadrupling of oil prices following the Arab-Israeli war of October 1973. In mid 1974 the copper price started to fall alarmingly. Moreover, despite the regime's initial efforts, inflation still seemed to be largely out of control. These mounting difficulties coincided with the consolidation of Pinochet's personal power. It was at this point (March 1975) that the assertive American guru of monetarism, Professor Milton Friedman, saw 
fit to visit Chile; he talked to Pinochet, emphasizing the need for "shock treatment" to eliminate inflation. In April 1975, after hearing the arguments and counter-arguments of economists at a weekend conference at Cerro Castillo [the Chilean Camp Davis], Pinochet threw caution to the winds, came down decisively in favor of the Chicago Boys, conferred extraordinary powers on Jorge Cauas (his finance minister since July 1974), and appointed Sergio de Castro [another Chicago Boy] as Economy Minister" [emphasis added]. ${ }^{4}$

Thus, history suggests that 1975 is a more appropriate year for the structural break than 1973 or 1974.

A few caveats are worth mentioning before concluding. First, the model used in this paper does not assume that political instability is the only cause of a fiscal policy imbalance. As mentioned in the introduction, a growing deficit can be explained by other reasons as well. But the model does imply that political instability makes fiscal policy imbalance and government financial crisis more likely to occur.

Second, the empirical work in this paper does not address causality directly and a question remains: Does political instability cause fiscal policy imbalance, or is it the other way around? Our empirical procedure is to search for periods in which the estimated tax-tilting parameter has a value less than one and therefore, periods during which government policy creates a fiscal policy imbalance. Next, we ask whether these are years in which there clearly was political instability in Chile. Because periods leading up to the civil war of 1891 and to the military coup of 1973 and the period during which General Pinochet was consolidating his power are clearly times of political instability, our results support our model, although not as strongly as a formal causality test would. But we do not have a long time series for a variable that represents the degree of political instability in Chile. Thus, it is impossible to use a more formal causality test and also impossible to estimate an appropriate VAR model that could be used to calculate how taxes and government spending respond to a one-standard-deviation structural shock to political stability.

Third, we have presented evidence from only one country. Does the way in which the tax-tilting parameter appears to depend on political instability in Chile hold in other countries as well, particularly those mentioned in the introduction? Pasten and Cover (2010b) use a series of political variables taken from the International Country Risk Guide (ICRG) as proxies for political instability , as well as data on fiscal policy from the Oxford Latin America Economic History Database, to examine the issue for a panel of 19 countries over a relatively short sample period. Their results support the proposition that an increase in political risk increases the degree of tax-tilting, suggesting that the results found for Chile hold for other Latin American countries as well.

\footnotetext{
${ }^{4}$ Collier and Sater (2004), page 365.
} 


\section{Conclusions}

This paper uses an intertemporal model of public finances to show that it is possible for political instability to cause unsustainably large government budget deficits. The model implies that governments respond to political instability by tilting taxes to the future (or increasing the current budget deficit), eventually weakening the government's fiscal condition. This suggests that when taxes are tilted to the future, it is more likely that political instability exists. On the other hand, if taxes are not tilted toward the future, it is more likely that there is political stability. The idea behind the model is that political instability affects the incentives faced by the government, causing it to undertake myopic fiscal policies in order to increase the probability of its survival in office. This is done by delaying taxes (or advancing spending) in order to buy political support, thereby imposing a positive trend on the deficit process.

Empirically, the paper examines tax-tilting along with the possible cointegration of taxes and government spending in Chile for the period 18331999. Overall, the process that the Chilean central government budget deficit followed for the whole sample was found to be stationary, implying that if government spending and taxes (as a share of output) are not stationary, they must be cointegrated. Searching endogenously for structural breaks in the cointegration vector between taxes and spending, we find that the periods with the highest probability of taxes being tilted toward the future coincide with periods of intense political unrest. Finally, we present evidence of there being at least two regimes in the fiscal-policy time series for Chile; a first regime in which taxes were on average tilted toward the future and a second regime with no tax-tilting. Formally, this implies that we reject the null hypothesis of no cointegration between taxes and government spending and accept the alternative of cointegration with a structural break after 1975, a period of both fiscal and political reforms.

\section{REFERENCES}

Barro, R.J. (1979), “On the Determination of the Public Debt.” Journal of Political Economy 87: 940-71.

Blanchard, O. (1985), "Debt, Deficits, and the Finite Horizons." Journal of Political Economy 93: 223-47.

Bohn, H. (2005), “The Sustainability of Fiscal Policy in the United States.” Working Paper $\mathrm{N}^{\circ} 1446$, CESifo.

Bohn, H. (2007), "Are Stationarity and Cointegration Restrictions Really Necessary for the Intertemporal Budget Constraint?" Journal of Monetary Economics, 54: $1837-1847$.

Caballero, R. and R. Dornbush (2002), “Argentina: A Rescue Plan that Works.” Financial Times op-ed, March.

Cashin, P., N. Olekalns, and R. Sahay (1998), "Tax Smoothing in a financially repressed economy: Evidence from India.” Working Paper WP/98/122. International Monetary Fund. 
Cashin, P., N. Haque, and N. Olekalns (1999), "Spend Now, Pay Later? Tax Smoothing and Fiscal Sustainability in South Asia." Working Paper WP/99/ 63. International Monetary Fund.

Cerda, R. and R. Vergara (2007), "Business Cycle and Political Election Outcomes: Evidence from the Chilean Democracy." Public Choice 132: 125-36.

Cerda, R. and R. Vergara (2008), "Government Subsidies and Presidential Election Outcomes: Evidence for a Development Country." World Development 36: $2470-88$.

Chang, R. (2007), "Financial Crises and Political Crises." Journal of Monetary Economics 54: 2409-20.

Collier, S. and W. F. Sater (2004), A History of Chile 1808-2002. Cambridge University Press.

Drazen, A. (2000), “The Political Budget Cycle After 25 Years.” NBER Macroeconomics Annual 2000. Cambridge MA: MIT Press.

Frankel, J. (2005), “Contractionary Currency Crashes in Developing Countries.” Working Paper $\mathrm{N}^{\circ} 11508$. National Bureau of Economic Research (NBER).

Gonzalez, M. (2002), "Do Changes in Democracy Affect the Political Budget Cycle? Evidence from Mexico." Review of Development Economics 6: 204-24.

Ghosh, A.R. (1995), "Intertemporal Tax-Smoothing and the Government Budget Surplus: Canada and United States." Journal of Money, Credit and Banking 27: 1033-45.

Gregory, A.W. and B.E. Hansen (1996), "Residual-Based Tests for Cointegration in Models with Regime Shifts." Journal of Econometrics 70: 99-126.

Haggard, S. (2000), "The Political Economy of the Asian Financial Crisis." Washington: Institute for International Economics.

Hakkio, C.S. and M. Rush (1991), "Is the Budget Deficit Too Large?" Economic Inquiry 29: 429-45.

Hamilton, D. and M. Flavin (1986), "On the Limitations of Government Borrowing: A Framework for Testing." American Economic Review 76: 808-19.

Huang, C. and K.S. Lin (1993), "Deficits, Governments Expenditures, and Tax Smoothing in the United States: 1929-1988." Journal of Monetary Economics 31: 317-39.

Johansen, S. (1988), "Statistical Analysis of Cointegration Vectors." Journal of Economic Dynamics and Control 12: 231-54.

Johansen, S. (1991), "Estimation and Hypothesis Testing of Cointegration Vectors in Gaussian Vector Autoregressive Models." Econometrica 59: 1551-1580.

Ng, S. and P. Perron (1995), "Unit Root Tests in ARMA Models with Data Dependent Methods for the Selection of the Truncation Lag." Journal of the American Statistical Association 90: 268-81.

Nordhaus, W. (1975), “The Political Business Cycle.” Review of Economics Studies 42: 169-90.

Olekalns, N. 1996. Australian evidence on tax smoothing and the optimal budget surplus. Research paper Nr. 538. The University of Melbourne. October.

Panzer, J. and R. Paredes (1991), “The Role of Economic Issues in Elections: The Case of the 1988 Chilean Presidential Referendum." Public Choice 71: 51-59.

Pasten, R. and J.P. Cover (2010 a), "Does the Chilean Government Smooth Taxes? A Tax-Smoothing Model with Revenue Collection from a Natural Resource." Applied Economics Letters, forthcoming.

Pasten, R. and J.P. Cover (2010 b). "Tax Tilting and Politics: Some Theory and Evidence for Latin America." Working Paper, Universidad de Talca. 
Quintos, C. (1995), "Sustainability of the Deficit Process with Structural Shift." Journal of Business and Economic Statistics 13: 409-17.

Rogoff, K. (1990), "Equilibrium Political Budget Cycles." American Economic Review 80: 21-36.

Solimano, A. (2003), "Governance Crisis and the Andean Region: A Political Economy Analysis." Macroeconomía del Desarrollo, 23. ECLAC. Santiago, Chile.

Trehan, B. and C.E. Walsh (1988), "Common Trends, the Government's Budget Constraint, and Revenue Smoothing." Journal of Economic Dynamics and Control $12,425-44$.

Trehan, B. and C.E. Walsh (1991), "Testing Intertemporal Budget Constrains: Theory and Applications to U.S. Federal Budget and Current Account Deficits." Journal of Money, Credit, and Banking 23: 206-23.

Wagner, G., J. Jofre, and R. Lüders (2000), “Economía Chilena 1810-1995. Cuentas Fiscales.” Documento de Trabajo 188. Pontificia Universidad Católica de Chile.

Yaari, M.E. (1965), "Uncertain Lifetime, Life Insurance, and the Theory of the Consumer." Review of Economics Studies 32, 137-50.

Zivot, E. and D.W.K. Andrews (1992), "Further Evidence on the Great Crash, the Oil Price Shock and Unit Root Hypothesis." Journal of Business and Economic Statistics 10: 251-70. 